\title{
Upaya Meningkatkan Hasil Belajar Kimia Siswa dengan Pendekatan Stuctured Exercise Methode (SEM) Melalui Kegiatan Laboraturium pada Siswa Kelas XI MIA 1 SMAN 4 Kerinci pada Materi Laju Reaksi
}

\author{
Syahdanur Gusmin R \\ SMA Negeri 4 Kerinci \\ Correspondence email: syahdanurrinda@gmail.com
}

\begin{abstract}
Abstrak. Penelitian ini bernama Penelitian Tindakan Kelas. Penelitian ini dilakukan karena banyak siswa yang mengalami kesulitan dalam memahami konsep-konsep kimia dan selama kegiatan belajar mengajar keaktifan siswa serta hasil belajar siswa masih rendah. Oleh karena itu penulis mencoba untuk menerapkan metode pembelajaran Structure Excercise Methode (SEM,) guna meningkatkan pemahaman konsep kimia dan keaktifan belajar serta hasil belajar siswa. Subjek penelitian adalah siswa kelas XI MIA 1 SMAN 4 Kerinci, manfaat dari penelitian ini agar pemahaman konsep kimia siswa meningkat, siswa lebih aktif dalam belajar dan hasil belajar siswa meningkat. Penelitian ini dibantu oleh rekan sesama guru mata pelajaran kimia, yang berperan sebagai kolaborator. Penelitian dilakukan sebanyak dua siklus dimana setiap siklus terdiri dari empat tahapan yaitu: (a) Perencanaan (b). Pelaksanaan (c). Observasi (d). Refleksi. Hasil Analisis data menunjukkan bahwa pemahaman konsep kimia, keaktifan siswa dan hasil belajar siswa meningkat signifikan setelah diterapkan metode pembelajaran Structure Excercise Methode (SEM). Nilai rata-rata hasil belajar kognitif naik dari sebelum adanya tindakan nilai rata-rata baru mencapai 61 (32\%), setelah dilakukan tindakan Pada siklus 1 meningkat menjadi 69 (52\%), pada siklus 2 meningkat menjadi 82 (84\%). Nilai hasil belajar Psikomotor tentang keaktifan belajar siswa pada siklus 1 mencapai 69 (60\%) pada siklus 2 mencapai 76 (80\%). Dapat disimpulkan bahwa penggunaan metode pembelajaran Structure Exercise Methode (SEM) dapat meningkatkan pemahaman konsep belajar kimia, keaktifan belajar siswa dan hasil belajar pada materi laju reaksi di kelas XI MIA 1 SMAN 4 Kerinci. Oleh karena itu disarankan kepada guru kimia menggunakan metode pembelajaran Structure exercise Metode (SEM) sebagai salah satu solusi untuk mengatasi permasalahan belajar siswa khususnya pada materi laju reaksi.
\end{abstract}

Kata Kunci: Structure Excercise Methode (SEM); pemahaman; keaktifan; hasil belajar

\begin{abstract}
This study was an action research. The research was conducted because there were some students who got difficulties in comprehending Chemistry Concepts, they were not active, and their learning achievements were still low. Therefore, the researcher offered a learning method called Structure Exercise Method (SEM) to improve the student's comrehension on Chemistry Concepts, learning activeness and achievement. The research participants were the students of grade XI MIA 1 SMAN 4 Kerinci. The researcher was helped by a collaborator who was also a teacher of Chemistry subject. The study was conducted in two cycles in four stages; (a) Planning (b) Action (c) Observation, (d) Reflection. The analysis data result showed that there were significant improvements on the student's comprehension toward Chemistry Concept, learning activeness and achievement after the Structure Exercise Methode (SEM) was implemented. The student's average score in precycle was only 61 (32\%), it improved to $69(52 \%)$ in cycle 1, then in cycle 2, it improved higher to 82 (82\%). Moreover, the student's phsychomotoric activeness' score in cycle 1 was $69(60 \%)$ and it became higher to 76 (80\%) in cycle 2. As a conclusion, the Structure Exercise Method (SEM) significantly improved the students' comprehension on the Chemistry consept, learning activeness and achievement on reaction Rate subject at grade XI MIA 1 SMAN 4 Kerinci. Therefore, it was suggested to Chemistry Teachers to apply this method as one of solution in teaching Chemistry especially on Reaction Rate Subject.
\end{abstract}

Keywords: Structure Excercise Methode (SEM); understanding; activeness; learning outcomes

\section{PENDAHULUAN}

Ilmu kimia merupakan ilmu yang mempelajari tentang susunan, struktur, sifat, perubahan serta energi yang menyertai perubahan suatu materi. Salah satu materi pokok dalam mata pelajaran kimia di SMA Kelas XI MIA adalah Laju reaksi. Pada materi laju reaksi terdapat materi berbentuk konsep (diantaranya: pengertian laju reaksi, orde reaksi, teori tumbukan, faktor yang mempengaruhi laju reaksi) juga perhitungan menggunakan rumus (diantaranya: menghitung molaritas, orde reaksi, laju reaksi). Siswa dituntut untuk memahami materi dengan baik agar pada saat evaluasi nanti mendapatkan nilai yang melebihi atau minimal sama dengan Kriteria Ketuntasan Minimal (KKM).

Berdasarkan hasil wawancara dan observasi di SMAN 4 Kerinci terhadap Siswa kelas XI MIA 1, pembelajaran kimia khususnya pada materi laju reaksi masih banyak siswa yang belum paham, karena guru menggunakan metode ceramah, kadang-kadang mengkombinasikannya dengan metode latihan (drill)

Seiring dengan berkembangnya dunia pendidikan, ditemukannya metode pembelajaran berbasis masalah (problem based learning) menciptakan suatu ruang baru dalam referensi metode pembelajaran guru. 
Pengkombinasian metode latihan dengan pembelajaran berbasis masalah (problem based learning) menciptakan metode pembelajaran baru yaitu Structured Exercise Method (SEM) atau latihan terstruktur.

SEM mempunyai perbedaan jika dibandingkan dengan Drill Method, yaitu SEM memperhatikan urutan penyajian atau penyampaian soal. Urutan ini didasarkan pada tingkat kesulitan penyelesaian tiap-tiap pertanyaan dalam soalnya. Urutan tersebut dimulai dari soal dengan tingkat kesulitan penyelesaian yang rendah (sederhana) menuju ke soal dengan tingkat kesulitan penyelesaian yang tinggi (kompleks).

Structured Exercise Method (SEM) adalah pemberian soal-soal latihan kepada siswa secara sistematis dan berurutan dimulai dari soal-soal yang sederhana ke soal-soal yang lebih kompleks. Metode ini merupakan hasil kombinasi antara metode latihan dan metode pemecahan masalah (Noralia, 2010). Setiap soal latihan berisikan konsep yang nantinya akan dikuasai setelah siswa dapat menjawabnya.

Dengan pengaturan penyajian atau pengurutan pemberian dari soal sederhana (yang berisikan konsep sederhana/mendasari konsep selanjutnya) menuju soal yang lebih kompleks (yang berisikan konsep yang lebih kompleks/kelanjutan dari konsep pada soal sebelumnya), dapat memudahkan siswa untuk memahami, pengurutan penyampaian konsep dalam mengajar.

Pertanyaan-pertanyaan penuntut yang digunakan oleh Structure Exercise Method (SEM) untuk merangsang gairah belajar siswa. Structure Exercise Method (SEM) pada pelaksanaanya, guru tidak melepaskan siswa begitu saja untuk menyelesaikan soal tersebut tetapi ikut membimbing siswa dalam menyelesaikannya, sehingga siswa akan berlatih untuk menyelesaikan soal secara sistematis dan runtut (Noralia, 2010). Sehingga dengan metode latihan berstruktur, para siswa akan merasa terbimbing secara baik dan dapat menyelesaikan soal-soal yang diberikan guru dengan benar.

Hasil belajar menurut Bloom dalam (Kurniawan, 2011) digolongkan menjadi 3 bagian yaitu kognitif, afektif dan psikomotor. Ranah kognitif berkaitan dengan hasil berupa pengetahuan, kemampuan dan kemahiran intelektual, dan tujuan pembelajaran ranah psikomotorik menunjukkan adanya kemampuan fisik seperti kemampuan motorik dan syaraf, manipulasi objek, dan koordinasi syaraf.

Dalam penelitian ini, hasil belajar yang dimaksud adalah perubahan pada diri siswa yang mencakup ranah kognitif yang dilihat dari hasil postest, dan ranah psikomotorik yang dilihat adalah perilaku yang mencerminkan keterampilan dan keaktifan pada saat kegiatan praktikum siswa adapun indikator penilaiannya yaitu : (a). Keseriusan siswa dalam mengikuti pelajaran (b). Keaktifan siswa dalam percobaan (c). Keaktifan siswa dalam mengajukan pertanyaan (d) Keaktifan siswa dalam menjawab pertanyaan (e). Persiapan siswa dalam mengikuti pembelajaran (f) Keseriusan siswa dalam mengejakan tes

\section{METODE \\ Subjek Penelitian}

Subjek dalam penelitian ini adalah siswa kelas XI MIA 1 SMA Negeri 4 Kerinci yang terdiri dari 25 orang siswa (15 orang siswa perempuan dan 10 orang siswa laki-laki).

\section{Jenis dan Desain Penelitian}

Jenis penelitian yang digunakan adalah Penelitian Tindakan Kelas (PTK). Eka warna (2010) Penelitian Tindakan Kelas (PTK) adalah yang dilaksanakan oleh guru di dalam kelas adapun tujuan dalam PTK adalah untuk menguji hipotesis dan membangun teori yang bersifat umum (general), selain itu juga bertujuan untuk memperbaiki kinerja.

\section{Waktu Penelitian}

Penelitian dilakukan pada bulan Agustus sampai November 2019 pada mata pelajaran kimia dengan materi Laju Reaksi di semester ganjil tahun pelajaran 2019/2020

\section{Tempat Penelitian}

Penelitian dilaksanakan di kelas XI MIA 1, SMA Negeri 4 Kerinci dengan alamat tutung bungkuk, Siulak, koto rendah kecamatan Siulak

\section{Teknik dan Instrumen Pengumpulan Data}

Penelitian ini dilakukan peneliti dengan mempersiapkan instrument terlebih dahulu sebelum penelitian dimulai dengan tujuan agar peneliti dapat merancang kesesuaian instrument berdasarkan data-data yang diperoleh di lapangan secara efektif dan efisien. Instrumen pengumpulan data yang digunakan antara lain:

\section{Observasi}

Melakukan pengamatan langsung pada kegiatan belajar mengajar di kelas. Observer melakukan pencatatan data berkaitan dengan fokus masalah yang diteliti yaitu keaktifan siswa dan tindakan yang dilakukan guru. Instrumen yang digunakan adalah lembar pengamatan/observasi yang akan digunakan untuk melaksanakan pengamatan.

\section{Teknik Evaluasi/ Tes}

Teknik ini digunakan untuk mengetahui perkembangan dan keberhasilan pelaksanaan tindakan. Adapun tes yang diberikan berupa tes tertulis dalam bentuk latihan-latihan soal dan tes akhir untuk mengetahui hasil belajar siswa. (Arikunto, 2009) 


\section{Dokumentasi}

Teknik ini digunakan untuk mendokumentasikan pelaksanaan penelitian berupa gambar-gambar untuk mendukung terpenuhinya sumber data yang meliputi aktivitas guru saat mengajar dan aktivitas siswa saat pembelajaran dan diskusi. (Arikunto, 2009).

\section{Wawancara}

Peneliti melakukan tanya jawab dengan nara sumber dalam hal ini guru dan siswa untuk mengetahui kondisi pembelajaran di dalam kelas sebagai data observasi awal.(Arikunto, 2009).

\section{Jenis Tindakan}

Penelitian ini merupakan penelitian tindakan kelas, yang dilaksanakan dalam dua siklus

Adapun tahapan-tahapannya adalah sebagai berikut:

a) Perencanaan

Pada tahap perencanaan ini dilakukan persiapan yang berhubungan dengan Pelaksanaan model pembelajaran Structure Exercise Method (SEM) seperti Identifikasi masalah, pembuatan rencana pembelajaran, pembuatan lembar kerja siswa, pembuatan lembar pengamatan siswa dan guru, penyediaan alat yang akan digunakan untuk percobaan.

b) Pelaksanaan Tindakan

Pelaksanaan tindakan merupakan kegiatan dilaksanakannya skenario pembelajaran yang telah direncanakan. Adapun tindakan yang dilakukan oleh guru adalah memberi tugas mandiri kepada siswa, membentuk kelompok, membimbing siswa melakukan percobaan, serta memberikan tes diakhir siklus.

\section{c) Pengamatan}

Pengamatan adalah suatu kegiatan mengamati jalannya pelaksanaan tindakan untuk memantau sejauh mana efek tindakan pembelajaran dengan menggunakan Model Pembelajaran Structure Exercise Method (SEM) pada pokok materi Laju Reaksi. Pengumpulan data pada tahap ini meliputi data nilai hasil belajar siswa dan data observasi.

d) Refleksi

Dengan data observasi berdasarkan tindakan peneliti dapat direfleksi apakah dengan model Pembelajaran Structure Exercise Method (SEM) dapat meningkatkan hasil belajar siswa. Hasil dari refleksi adalah diadakannya perbaikan terhadap perencanaan yang telah dilaksanakan, yang akan digunakan untuk memperbaiki kinerja guru pada siklus selanjutnya.

\section{Uji Validitas dan Realiabilitas Instrumen}

Validitas instrumen dalam penelitian ini dilakukan dengan validitas konstruk. Dimana setelah butir instrumen selesai disusun berdasarkan kisi-kisi instrumen kemudian peneliti mengkonsultasikan dengan, Rekan guru inti kimia kemudian meminta pertimbangan (judgement expert) sebelum dilakukan pengambilan data. Keabsahan data setelah data diperoleh kemudian dikumpulkan, dicatat dan diusahakan kebenaranya dengan menggali data yang diperlukan. Analisa data dalam penelitian tindakan kelas, analisis dilakukan peneliti sejak awal pada setiap aspek kegiatan penelitian.

Data yang diperoleh pada penelitian tindakan kelas ini berupa data hasil observasi dan menggunakan teknik analisis deskriptif dengan presentase. Selain itu analisis data pada penelitian ini didasarkan pada refleksi tiap siklus tindakan. Hal ini bermanfaat untuk rencana perbaikan pembelajaran pada siklus berikutnya.

Analisis Data pada penelitian ini digunakan metode deskriptif dengan membandingkan hasil belajar sebelum adanya tindakan dengan hasil belajar setelah adanya tindakan. Data dihitung dengan langkah-langkah sebagai berikut: (a). Merekapitulasi hasil belajar sebelum dilakukan tindakan dan nilai tes akhir siklus I dan siklus II. (b). Menghitung nilai rata-rata dan ketuntasan belajar klasikal hasil belajar siswa sebelum dilakukan tindakan dengan hasil belajar setelah dilakukan tindakan pada siklus I, siklus II, untuk mengetahui adanya peningkatan hasil belajar.

Analisis data dari observasi kegiatan siswa dengan merefleksikan hasil pengamatan berupa keaktifan belajar siswa dianalisis dengan langkahlangkah menghitung perolehan masing-masing dari 6 indikator dan membagi dengan perolehan maksimal.

Rumus persentase keaktifan belajar siswa adalah sebagai berikut :

$\mathrm{P}=\frac{f}{N} \times 100$

Keterangan :

$\mathrm{P}=$ Angka persentase

$\mathrm{F} \quad=$ Frekuensi yang sedang dicari persentasenya

$\mathrm{N} \quad=$ Jumlah frekuensi/ banyaknya individu

(Anas Sudijono,2006:43)

Rata-rata hasil belajar siswa dihitung dengan menggunakan rumus:

$\mathrm{X}=\frac{\Sigma X}{N} \times 100 \%$

(Slameto, 2001:181)

Keterangan

$X \quad=$ Rata-rata hasil belajar

$\Sigma X \quad=$ Jumlah nilai seluruh siswa

$\mathrm{N} \quad=$ Banyaknya siswa

Ketuntasan belajar klasikal siswa dihitung dengan menggunakan rumus:

$\mathrm{P}=\frac{\Sigma n 1}{\Sigma n} \times 100 \%$

Keterangan:

$\mathrm{P} \quad=$ Nilai ketuntasan belajar klasikal 
$\Sigma \mathrm{n} 1=$ Jumlah siswa tuntas belajar individu (nilai $\geq$

70)

$\Sigma \mathrm{n} \quad=$ Jumlah total siswa

Hasil belajar kognitif siswa dapat dihitung dengan menggunakan rumus sebagai berikut:

Nilai $=\frac{\sum \text { Jawaban Benar }}{\sum \text { Seluruh Soal }} \times 100$

(Departemen Pendidikan Nasional, 2003)

\section{Kriteria Keberhasilan}

Kriteria merupakan patokan untuk menentukan keberhasilan suatu kegiatan atau program, dikatakan berhasil apabila mampu mencapai kriteria yang telah ditentukan dan gagal apabila tidak mampu melampaui kriteria yang telah ditentukan, siswa yang memperoleh skor keaktifan belajar siswa adalah $\geq 75 \%$ yang mengacu pada E. Mulyasa (2008:101) bahwa dari segi proses, pembelajaran dikatakan berhasil dan berkualitas apabila seluruhnya atau setidaknya sebagian besar (75\%) siswa terlibat secara aktif dalam proses pembelajaran yang terlihat dari enam indikator dalam penelitian ini yaitu: (a). Keseriusan siswa dalam mengikuti pelajaran (b). Keaktifan siswa dalam percobaan (c). Keaktifan siswa dalam mengajukan pertanyaan (d) Keaktifan siswa dalam menjawab pertanyaan (e). Persiapan siswa dalam mengikuti pembelajaran (f) Keseriusan siswa dalam mengejakan tes.

\section{HASIL DAN PEMBAHASAN \\ Pra siklus}

Pelaksanaan pembelajaran Pra siklus adalah pembelajaran yang berpusat pada guru dimana guru sebagai pusat informasi, guru mengamati keaktifan siswa dengan lembar observasi dengan enam indikator keaktifan. Hasil observasi menunjukkan bahwa indikator pertama yaitu Keseriusan siswa dalam mengikuti pelajaran sebesar $24,00 \%$ dari skor maksimal, indikator kedua Keaktifan siswa dalam percobaan sebesar 48.00 $\%$, indikator ketiga Keaktifan siswa dalam mengajukan pertanyaan $28,00 \%$, indikator ke empat Keaktifan siswa dalam menjawab pertanyaan sebesar $16.00 \%$, indikator ke lima Persiapan siswa dalam mengikuti pembelajaran $24.00 \%$, serta indikator ke enam keseriusan siswa dalam mengejakan tes sebesar $48.00 \%$. Capaian hasil belajar kognitif siswa sebelum dilakukan tindakan baru mencapai nilai rata-rata 61 atau $32 \%$.

\section{Siklus 1}

Siklus pertama dalam penelitian ini dengan menerapkan metode pembelajaran Structure Exercise Method (SEM) untuk mengatasi tingkat permasalahan keaktifan siswa dan hasil belajar, tindakan dilakukan oleh peneliti dan pengamatan dilakukan oleh kolaborator atas segala yang terjadi saat pelaksanaan tindakan.

\section{Perencanaan}

a) Merancang skenario pembelajaran dengan pendekatan Structure Exercise Method (SEM). meliputi rencana pembelajaran dan Lembar Kerja Siswa.

b) Menyusun alat evaluasi untuk mengukur penguasaan materi pelajaran kognitif, psikomotorik.

c) Menyiapkan lembar observasi untuk mengamati situasi dan kondisi selama kegiatan belajar mengajar berlangsung. Observasi dilakukan oleh peneliti yang bertindak sebagai guru dan guru mitra secara kolaborasi untuk mengamati kegiatan secara keseluruhan. Lembar observasi terdiri dari dua jenis yaitu lembar observasi untuk mengamati kondisi siswa dan lembar observasi untuk mengamati kinerja guru.

d) Menyiapkan lembar angket refleksi siswa.

\section{Pelaksanaan}

a). Guru memberikan informasi awal tentang jalannya pembelajaran dan tugas yang harus dilaksanakan siswa. b). Secara mandiri, siswa diminta membuat pertanyaan yang disertai jawaban mengenai pokok materi yang dipelajari. c). Guru memeriksa tugas siswa. d). Guru mengadakan pre-test untuk mengetahui kesiapan siswa dalam proses pembelajaran. e).Guru membagi siswa menjadi lima kelompok yang tiap kelompok beranggotakan lima siswa. f). Guru membagi Lembar Kerja Siswa. g). Guru membimbing siswa melakukan percobaan. h) memecahkan masalah yang diberikan dan mencatat hasil pengamatan dalam LKS. i). Setelah selesai wakil dari kelompok masing-masing mempresentasikan hasil percobaan untuk didiskusikan dan ditarik kesimpulan. J). Pada pertemuan berikutnya, dengan menggunakan metode tanya jawab guru membahas materi berikutnya. k). Pada akhir siklus guru memberikan soal tes siklus I, lembar angket refleksi

\section{Pengamatan}

a). Guru memeriksa tugas siswa untuk mengidentifikasi kemampuan siswa dalam belajar mandiri. b). Guru dan guru mitra mengamati jalannya proses pembelajaran dan menilai kemampuan siswa dalam menyelesaikan tugas dalam kelompoknya. c). Guru mengamati kemampuan siswa dalam mempresentasikan hasil percobaan. d). Menganalisa data hasil tes siklus 1 serta hasil observasi.

Berdasarkan lembar observasi dapat diketahui bahwa setelah diterapkan model pembelajaran dengan pendekatan Structure Exercise Method (SEM), keaktifan siswa menunjukkan indiktor keseriusan siswa dalam mengikuti pelajaran sebesar $60 \%$, indikator kedua keaktifan siswa dalam percobaan sebesar $64 \%$, indikator ketiga keaktifan siswa dalam mengajukan pertanyaan, $60 \%$, indikator ke empat keaktifan siswa dalam menjawab pertanyaan sebesar.60\%, indikator ke lima persiapan siswa dalam mengikuti pembelajaran $64 \%$, serta indikator ke enam keseriusan siswa dalam mengejakan tes sebesar $72 \%$. 
Sedangkan pada lembar observasi Pengamatan terhadap guru menghasilkan :

Guru kurang memberi motivasi siswa saat pembelajaran berlangsung, guru kurang membawa siswa untuk mengaitkan materi dengan peristiwa kehidupan, teknik bertanya yang dimiliki guru belum maksimal, pengelolaan kelas kurang optimal, pengelolaan waktu kurang optimal

Setelah melaksanakan pengamatan terhadap pelaksanaan pembelajaran di kelas kemudian diadakan refleksi dari tindakan yang telah dilakukan. Pada tindakan siklus I didapatkan hasil sebagai berikut: (1). guru lebih meningkatkan minat siswa yaitu dengan memberikan penguatan kepada siswa selama proses pembelajaran berlangsung dengan cara lebih membuka wawasan siswa untuk melihat fenomena alam yang ada dan mengaitkan dengan materi yang diajarkan. (2). teknik bertanya yang dimiliki guru perlu ditingkatkan (3). pengelolaan waktu harus lebih baik (4). pengelolaan kelas harus lebih baik

Berdasarkan hasil postest siswa pada siklus 1 mengalami peningkatan nilai rata-rata dari pra siklus yang baru mencapai nilai rata-rata 61 meningkat menjadi 69 pada siklus I, atau meningkat dari $32 \%$ menjadi $52 \%$.

\section{Siklus II}

Pada siklus ini dilakukan empat rangkaian kegiatan yaitu perencanaan, tindakan, pengamatan dan refleksi. Berdasarkan data yang diperoleh dari proses kegiatan belajar mengajar pada siklus 1 .

Berdasarkan hasil observasi dan refleksi dapat diidentifikasi masalah-masalah yang dapat menghambat naiknya hasil belajar siswa sehingga dapat diambil langkah perbaikan pada siklus II ini. Siklus II merupakan kelanjutan dari siklus I.

\section{Perencanaan}

a) Merancang skenario pembelajaran dengan pendekatan Structure Exercise Method (SEM), meliputi rencana pembelajaran dan Lembar Kerja Siswa. b) Menyusun alat evaluasi untuk mengukur penguasaan materi pelajaran baik dari segi kognitif, dan maupun psikomotorik

c) Menyiapkan lembar observasi untuk mengamati situasi dan kondisi selama kegiatan belajar mengajar berlangsung.

d) Menyiapkan lembar angket refleksi siswa.

\section{Pelaksanaan}

a) Secara mandiri, siswa diminta membuat pertanyaan yang disertai jawaban mengenai pokok materi yang dipelajari .

b) Guru memeriksa tugas siswa.

c) Guru membagi siswa menjadi lima kelompok yang tiap kelompok beranggotakan lima orang siswa.

d) Guru membagi Lembar Kerja Siswa.

e) Guru membimbing siswa melakukan percobaan untuk memecahkan masalah yang diberikan dan mencatat hasil pengamatan dalam LKS.

f) Setelah selesai wakil dari kelompok masing-masing mempresentasikan hasil percobaan untuk didiskusikan dan ditarik kesimpulan.

g) Pada pertemuan berikutnya, dengan menggunakan metode tanya jawab guru membahas materi berikutnya.

h) Pada akhir siklus guru memberikan soal tes siklus II dan lembar observasi.

\section{Pengamatan}

a) Guru memeriksa tugas siswa untuk mengidentifikasi kemampuan siswa dalam belajar mandiri

b) Guru mengamati jalannya proses pembelajaran dan menilai kemampuan siswa dalam menyelesaikan tugas dalam kelompoknya.

c) Guru mengamati kemampuan siswa dalam mempresentasikan hasil percobaan.

d) Menganalisa data hasil tes siklus II serta hasil observasi.

Berdasarkan lembar observasi pada siklus 2 dapat dilihat pada tabel berikut ini :

Tabel 1. Persentasi keaktifan siswa per siklus berdasarkan instrumen Observasi

\begin{tabular}{clccc}
\hline No & \multicolumn{1}{c}{ Indikator } & Pra Siklus 1 (\%) & Siklus 1 (\%) & Siklus II (\%) \\
\hline 1 & Keseriusan siswa dalam mengikuti pelajaran & 24 & 60 & 84 \\
2 & Keaktifan siswa dalam percobaan & 48 & 64 & 80 \\
3 & Keaktifan siswa dalam mengajukan pertanyaan & 28 & 60 & 76 \\
4 & Keaktifan siswa dalam menjawab pertanyaan & 16 & 60 & 76 \\
5 & Persiapan siswa dalam mengikuti pembelajaran & 24 & 64 & 84 \\
6 & Keseriusan siswa dalam mengejakan tes & 48 & 72 & 100 \\
\hline
\end{tabular}

Dari tabel diatas diketahui bahwa setelah diterapkan model pembelajaran dengan pendekatan Structure Exercise Method (SEM), keaktifan siswa menunjukkan indiktor keseriusan siswa dalam mengikuti pelajaran sebesar $84 \%$, indikator kedua keaktifan siswa dalam percobaan sebesar $80 \%$, indikator ketiga keaktifan siswa dalam mengajukan pertanyaan, $76 \%$, indikator ke empat keaktifan siswa dalam menjawab pertanyaan sebesar.76 \%, indikator ke lima persiapan siswa dalam mengikuti pembelajaran $84 \%$, serta indikator ke enam keseriusan siswa dalam mengejakan tes sebesar $100 \%$. 


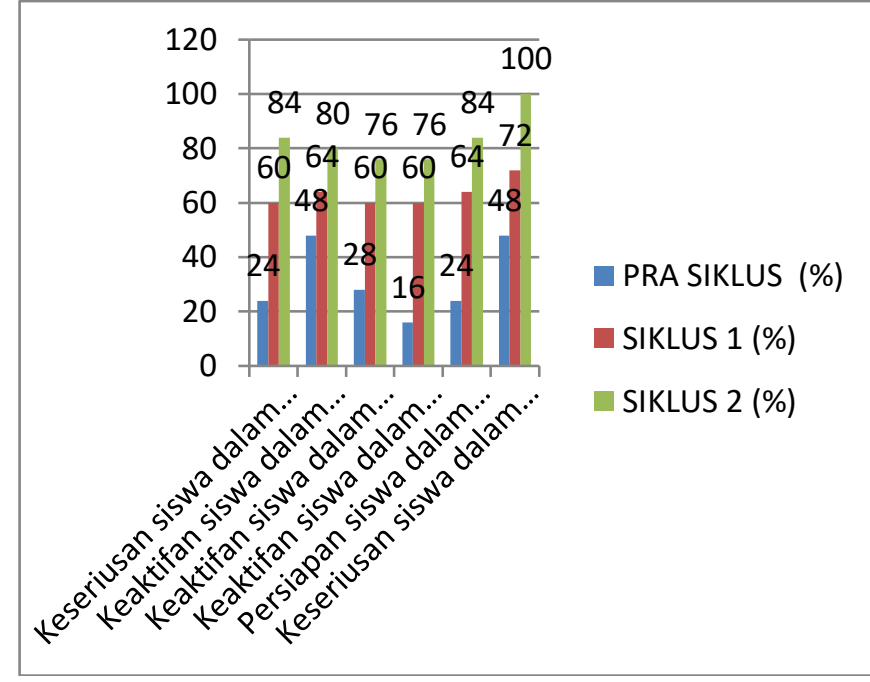

Gambar 1. Diagram Batang Peningkatan nilai Keaktifan Siswa pada psikomotorik siswa per-Siklus

\section{Pembahasan \\ Hasil Belajar Siswa}

Penilaian hasil belajar kognitif siswa diperoleh dari tes pada tiap akhir siklus. Soal tes siklus yang digunakan untuk mengukur penguasaan kompetensi dan tingkat pemahaman siswa sebelum digunakan telah diujicobakan terlebih dahulu pada siswa kelas XI MIA 1 yang telah memperoleh materi laju reaksi. Soal yang tidak memenuhi syarat dibuang dan yang memenuhi syarat digunakan.

Berdasarkan hasil tindakan dari siklus I sampai siklus II maka hasil belajar kognitif siswa dapat disajikan dalam tabel dan diagram sebagai berikut:

Tabel 2. Ringkasan Hasil Belajar Kognitif Siswa

\begin{tabular}{ccccc}
\hline \multirow{2}{*}{ No. } & Keterangan & Sebelum & \multicolumn{2}{c}{ Setelah Tindakan } \\
Tindakan & Siklus I & Siklus II \\
\hline 1. & Nilai tertinggi & 75 & 80 & 100 \\
2. & Nilai terendah & 20 & 50 & 70 \\
3. & Rata-rata nilai & 61 & 69 & 82 \\
& Ketuntasan (\%) & $\mathbf{3 2 \%}$ & $\mathbf{5 2 \%}$ & $\mathbf{8 4 \%}$ \\
\hline
\end{tabular}

Setelah diterapkan model pembelajaran dengan pendekatan Structure Exercise Method (SEM), hasil belajar kognitif siswa mengalami peningkatan. Nilai rata-rata dari 61 meningkat menjadi 69 pada siklus I, 82 pada siklus II . Peningkatan hasil belajar tersebut menunjukkan bahwa tingkat pemahaman siswa terhadap materi pelajaran kimia semakin meningkat.

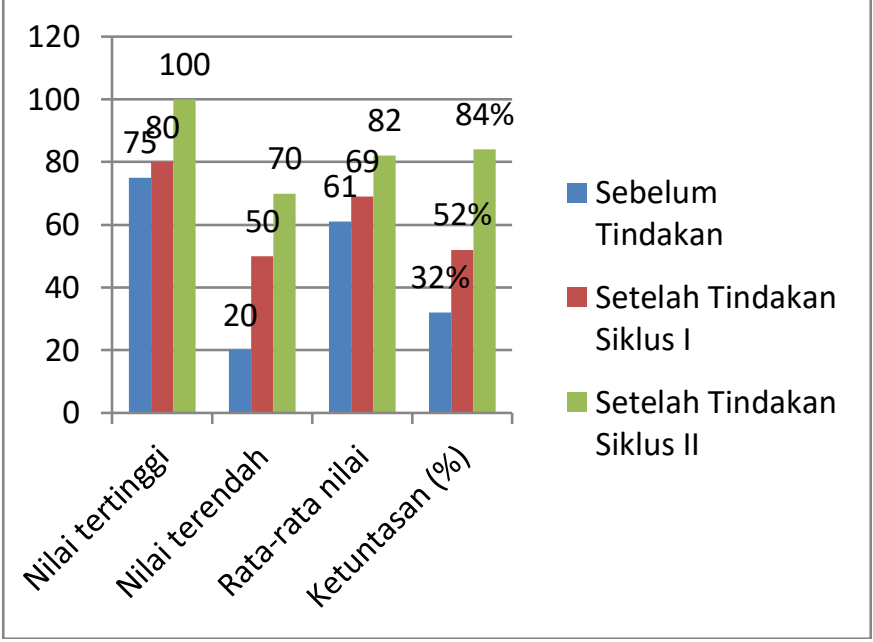

Gambar 2. Diagram Batang Peningkatan Hasil Belajar Siswa dan ketuntasan Belajar kognitif siswa Pra siklus, Siklus 1, Siklus 2

Penilaian hasil belajar kognitif siswa diperoleh dari hasil postest pada tiap akhir siklus. Soal tes siklus yang digunakan untuk mengukur penguasaan kompetensi dan tingkat pemahaman laju reaksi.

Berdasarkan pada tabel 2 dapat diketahui bahwa setelah diterapkan model pembelajaran dengan pendekatan Structure Exercise Method (SEM), hasil belajar kognitif siswa mengalami peningkatan. Nilai rata-rata dari 61 meningkat menjadi 69 pada siklus I, kemudian meningkat menjadi 82 pada siklus II . Peningkatan hasil belajar tersebut menunjukkan bahwa tingkat pemahaman siswa terhadap materi pelajaran kimia semakin meningkat.

Pada hasil belajar psikomotorik siswa juga mengalami peningkatan, nilai rata-rata psikomotorik siswa yaitu 69 pada siklus I, meningkat menjadi 76 pada siklus II. Peningkatan hasil belajar psikomotorik ini juga ditandai dengan peningkatan ketuntasan secara klasikal, yaitu $60 \%$ pada siklus I kemudian meningkat menjadi $80 \%$ pada siklus II. Ini berarti bahwa hasil belajar psikomotorik siswa siklus I, siklus II, sudah tuntas.

Berdasarkan hasil tindakan dari siklus I sampai siklus II maka hasil belajar Psikomotor siswa dapat disajikan dalam tabel dan diagram sebagai berikut:

Tabel 3. Ringkasan hasil Belajar Psikomotorik Siswa

\begin{tabular}{clcc}
\hline No. & \multicolumn{1}{c}{ Keterangan } & Siklus I & Siklus II \\
\hline 1. & Nilai tertinggi & 75 & 90 \\
2. & Nilai terendah & 58 & 70 \\
3. & Rata-rata nilai & 69 & 76 \\
& Ketuntasan (\%) & $\mathbf{6 0 \%}$ & $\mathbf{8 0 \%}$ \\
\hline
\end{tabular}




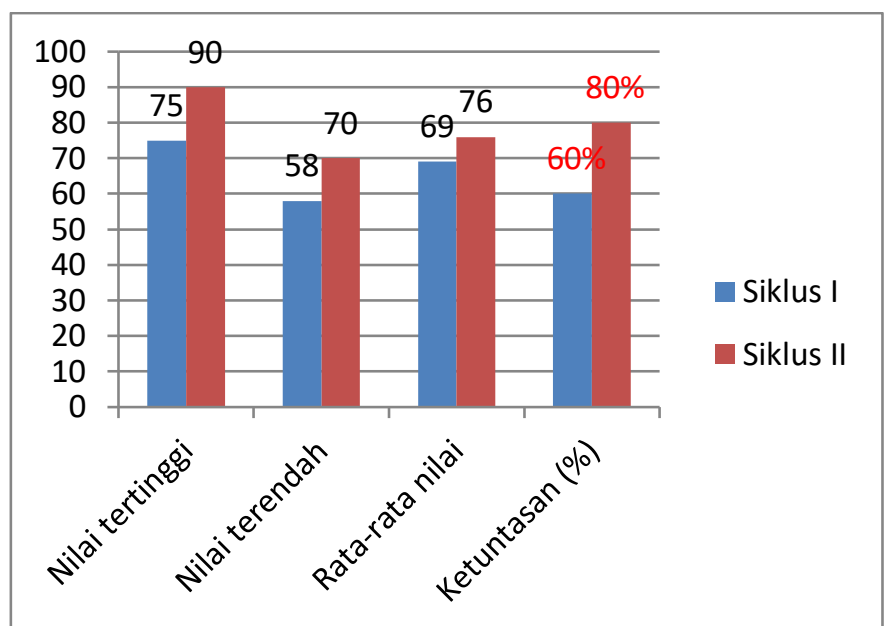

Gambar 3. Diagram Batang Peningkatan Hasil Belajar Siswa dan ketuntasan belajar psikomotorik siswa Pra siklus, Siklus 1, Siklus II

Berdasarkan deskripsi hasil belajar pada siklus I, siklus II memperlihatkan bahwa penggunaan model pembelajaran dengan pendekatan Structure Exercise Method (SEM) dapat meningkatkan hasil belajar kimia siswa. Keaktifan siswa terhadap pembelajaran dengan menggunakan Structure Exercise Method (SEM) juga dapat mempengaruhi hasil belajar siswa. Berdasarkan hasil pengamatan dari siklus I sampai siklus II ternyata keaktifan siswa juga mengalami peningkatan.

Dari hasil observasi tersebut menunjukkan bahwa pada siklus I masih ada beberapa siswa yang belum siap dalam mengikuti pembelajaran. Namun pada siklus 2 semua siswa telah menunjukkan kesiapannya dalam mengikuti pembelajaran. Hal ini dikarenakan guru selalu memberikan motivasi dan penguatan kepada siswa untuk selalu mempersiapkan hal-hal yang diperlukan dalam proses pembelajaran.

\section{SIMPULAN}

Berdasarkan hasi penelitian dan pembahasan dapat disimpulkan bahwa penerapan model pembelajaran dengan pendekatan Structure Exercise Method (SEM) pada mata pelajaran kimia khususnya pada pokok bahasan Laju Reaksi dapat meningkatkan hasil belajar siswa kelas XI MIA 1 SMAN 4 Kerinci. Hal ini ditandai dengan meningkatnya nilai rata-rata hasil belajar siswa. Sebelum penerapan model pembelajaran dengan pendekatan Structure Exercise Method (SEM) nilai ratarata kognitif siswa 61 dengan ketuntasan $32 \%$ dan setelah penerapan model pembelajaran dengan pendekatan Structure Exercise Method (SEM) menjadi 69 dengan ketuntasan klasikal 52\% pada siklus I, kemudian meningkat menjadi 82 dengan ketuntasan klasikal $84 \%$ pada siklus 2. Sedangkan hasil belajar psikomotorik siswa juga mengalami peningkatan dari 69 dengan ketuntasan $60 \%$ siklus I, menjadi 76 dengan ketuntasan $80 \%$ pada siklus 2. Dengan demikian target peneliti telah tercapai.
Oleh karena itu disarankan kepada guru kimia agar menggunakan metode pembelajaran Structure exercise Metode (SEM) sebagai salah satu solusi untuk mengatasi permasalahan belajar siswa khususnya pada materi laju reaksi.

\section{DAFTAR PUSTAKA}

Aksara Noralia, P.Y. 2010. Efektivitas Pembelajaran Structur Berbantuan mind map hasil belajar dan kemampuan memecahkan maaslah kimia materi pokok Reaksi Redox kelas X SMA

Anas Sudijono,(2006). Pengantar evaluasi Pendidikan,Jakarta : Rajawali Press

Arikunto, Suharsimi. 2009. DasarDasarEvaluasiPendidikan. Jakarta: BumiAksara

Dahar, R.W, 1996. Teori-teori belajar, Erlangga:Jakarta

Depdiknas 2007 Supervisi dan PKG. Direktorat Jenderal Guru dan Tenaga Kependidikan

E. Mulyasa. 2008. Menjadi Guru Profesional Menciptakan Pembelajaran Kreatif dan Menyenangkan. Bandung : PT. Remaja Rosdakarya.

Kurniawan, D. (2011). Pembelajaran Terpadu. Bandung: Pustaka Cendikia umum

Rochmad, 2013, Problem Based Learning universitas semarang

Slameto.(2003). Belajar dan Faktor-faktor yang mempengaruhinya. Jakarta; Rineka Cipta

Sudjana, Nana. 1989. Penilaian Hasil Proses BelajarMengajar. Bandung: PT. Remaja Rosda Karya

Warna, Eka. 2010,Penelitian Tindakan Kelas, Unja Jambi 